\title{
Uji Kinerja Mesin Pengiris Singkong Tipe Vertikal
}

\section{Performance Test of Cassava Slicing Machine (Vertical Type)}

\author{
Annisa Nur Ichniarsyah ${ }^{1 凶}$, Eka Widiono $^{1}$, Titis Pury Purboningtyas ${ }^{1}$ \\ ${ }^{1}$ Jurusan Pertanian, Politeknik Pembangunan Pertanian Bogor \\ ${ }^{\square}$ Komunikasi Penulis, email: annisanurichniarsyah@gmail.com \\ DOI:http://dx.doi.org/10.23960/jtep-lv10i4.530-536 \\ Naskah ini diterima pada 25 November 2021; revisi pada 20 Desember 2021; \\ disetujui untuk dipublikasikan pada 25 Desember 2021
}

\begin{abstract}
Several efforts to improve the efficiency and effectiveness of slicing cassava machine had been conducted One of them including the development of a prototype cassava slicing machine. This machine has types and classification based on slicing capacity. The purpose of this study was to conduct a machine performance test (verification test, performance test, and ergonomics test), to compare its performance with SNI 0838-1:2014, to analyze the constraints of a vertical cassava slicing machine. A quantitative research approach and descriptive explanatory method were used by observing, measuring, and calculating, the testing of cassava slicing machine. Verification test was to check the suitability of the type and type of engine, motor, transmission type, slicing unit, engine frame, and other supporting components in accordance with the specifications. The performance results of the slicing machine displayed that its capacity was $18.51 \mathrm{~kg} /$ hour and performance efficiency of $74.05 \%$. The slicing test obtained an average thickness was $0.73 \mathrm{~mm}$, uniformity level of $64.2 \%$, and damage rate around 9.67\%. Ergonomics tests showed that the machine was quite in accordance with the comfort of the operator. There were some obstacles that need evaluations such as the difficulty in adjusting slicing blade, transmission, and technical specifications of the cassava slicing machine. Therefore, the cassava slicing machine needed improvement so that it conforms to the requirements that refer to SNI 0838-1:2014.
\end{abstract}

Keywords: cassava, performance test, slicing, slicing machine, testing

\begin{abstract}
ABSTRAK
Upaya meningkatkan efisiensi dan efektivitas pengirisan singkong antara lain pengembangan prototipe mesin pengiris singkong. Mesin pengiris singkong memiliki tipe dan kelas berdasarkan kapasitas pengirisan. Tujuan penelitian ini untuk melakukan uji kinerja mesin (uji verifikasi, uji unjuk kerja, dan uji ergonomi), membandingkan kinerja mesin dengan SNI 0838-1:2014, menganalisis kendala mesin pengiris singkong vertikal. Penelitian ini menggunakan pendekatan penelitian kuantitatif dan menggunakan metode deskriptif eksplanatori dengan melakukan pengamatan, pengukuran serta penghitungan, pengujian dari mesin pengiris singkong. Hasil uji verifikasi menunjukkan bahwa jenis dan tipe mesin, motor penggerak, jenis transmisi, unit pengiris, kerangka mesin, dan komponen pendukung lainnya telah sesuai dengan spesifikasi mesin pengiris. Hasil unjuk kerja mesin pengiris menunjukkan bahwa mesin memiliki kapasitas 18,51 kg/jam dengan efisiensi kinerja 74,05\%. Hasil uji pengirisan diperoleh ketebalan rata-rata sebesar $0,73 \mathrm{~mm}$, tingkat keseragaman $64,2 \%$, dan memiliki nilai kerusakan irisan sebesar 9,67\%. Hasil uji ergonomi pada mesin yang diproduksi cukup sesuai dengan kenyamanan operator. Kendala yang dialami saat pengoperasian mesin terletak pada pisau pengiris, transmisi, spesifikasi teknis mesin pengiris singkong. Hasil evaluasi menunjukkan mesin pengiris singkong perlu diperbaiki agar sesuaian dengan persyaratan yang mengacu pada SNI 0838-1:2014.
\end{abstract}

Kata Kunci: mesin pengiris, pengiris, pengujian, singkong, unjuk kerja

\section{PENDAHULUAN}

Singkong merupakan tanaman pangan yang banyak ditanam dan diproduksi dengan skala kecil hingga besar. Berdasarkan data yang diperoleh dari Badan Pusat Statistik (2021) di Kabupaten Bogor, luas lahan tanam singkong sebesar 3.758 ha dan dapat menghasilkan produksi singkong sebesar 85.861 ton dan memiliki produktivitas panen sebesar 232,08 
ton/ha. Handayani dan Marwanti (2011) berpendapat bahwa pengolahan pasca panen diperlukan, mengingat masa segar singkong hanya bertahan 2 hari penuh sejak dipanen. Salah satu cara pengolahan produk singkong adalah keripik singkong. Proses produksi untuk mendapatkan irisan yang tipis secara manual cukup lama dan hal tersebut membutuhkan kesabaran tinggi (Widiyarta et al., 2018). Usaha yang masih mengandalkan cara kerja manual dengan cara tersebut akan sulit berkembang dan kalah saing dengan industri lainnya. Permasalahan yang dihadapi kelompok usaha kecil seperti: 1) kapasitas produksi keripik singkong masih rendah, 2) proses pengemasan masih manual dan konvensional (Suriadi et al, 2016). Sehingga, pengolahan pascapanen singkong membutuhkan alat dan mesin pertanian yang sesuai.

Sateria dan Darta (2020) mengemukakan bahwa alat pengiris manual masih kurang efektif karena mata pisau yang dipakai pada alat pengiris manual ini mudah rusak dan dapat dikatakan hasilnya kurang produktif. Hasil penelitian Husman dan Ariyono (2018) tentang rancang bangun mesin pengiris singkong menyatakan bahwa mesin pengiris singkong yang dipabrikasi dapat mempercepat proses pengirisan singkong. Mesin pengiris ini meningkatkan kapasitas pengirisan manual yang semula $30 \mathrm{~kg} / \mathrm{jam}$ menjadi $96 \mathrm{~kg} / \mathrm{jam}$.

Mesin pengiris singkong yang diteliti merupakan mesin tipe vertikal dan digerakkan oleh motor bensin dengan daya 4,1 kW. Mesin ini mempunyai empat buah mata pisau yang mampu mengiris tipis singkong dengan rancangan kapasitas mencapai $25 \mathrm{~kg} / \mathrm{jam}$. Perancangan mesin membutuhkan pengujian mesin untuk mengetahui performa/kinerja mesin dan mengetahui kekurangan-kekurangan pada mesin yang telah dibuat seperti yang dikemukakan oleh Azharul et al. (2020).

Mesin pengiris singkong tipe vertikal telah dirancang dan dipabrikasi. Akan tetapi, belum dilakukan uji kinerja. Penelitian sebelumnya tentang mesin pengiris singkong telah banyak dibahas tentang bentuk dan kapasitasnya tetapi sangat sedikit penelitian yang mengkaji mesin dari kendala dan kelayakan mesin pengiris.
Berdasarkan permasalahan tersebut perlu penelitian uji kinerja mesin dengan melihat standar kelayakan serta mengevaluasi kendala yang dialami untuk memastikan kualitas mutu serta saran masukan bagi perusahaan. Tujuan penelitian ini adalah: 1) Menguji kinerja mesin pengiris singkong vertikal dengan melakukan uji verifikasi, unjuk kerja mesin, dan menguji ergonomi dari mesin, 2) Membandingkan kinerja mesin pengiris singkong berdasarkan Standar Nasional Indonesia SNI 0838-1:2014 tentang mesin pengolah singkong, dan 3) Menganalisis kendala-kendala selama proses pengirisan singkong menggunakan mesin pengiris singkong vertikal untuk dijadikan saran perbaikan atau modifikasi mesin pengiris singkong.

\section{BAHAN DAN METODE}

Bahan yang digunakan dalam uji kinerja mesin pengiris singkong yaitu singkong seberat $8 \mathrm{~kg} /$ uji coba. Alat yang digunakan adalah mesin pengiris singkong vertical yang telah dipabrikasi, timbangan digital, stopwatch, sound level meter, vibration meter, tachometer, jangka sorong, meteran, dan mikrometer digital.

Jenis atau pendekatan kajian yang digunakan dalam penelitian ini adalah pendekatan penelitian kuantitatif dengan menggunakan metode deskriptif eksplanatori. Sugandi et al. (2017) menjelaskan bahwa analisis deskriptif eksplanatori yaitu melakukan pengamatan, pengukuran serta penghitungan, pengujian kinerja dari mesin pengiris singkong. Analisis data yang digunakan dalam penelitian ini mencakup beberapa parameter pengujian seperti yang ditunjukkan dalam Tabel 1 .

\subsection{Formulasi}

1. Kapasitas teoretis pengirisan

Kapasitas teoretis mesin pengiris singkong dapat dihitung dengan persamaan sebagai berikut (Pasaribu, 2017):

$$
K t=n * 60 * N c * V * \rho
$$

dimana $n$ adalah putaran as dudukan pisau pengiris (RPM), Kt adalah kapasitas teoritis (kg/ jam), Nc adalah jumlah pisau pengiris, $v$ adalah volume singkong $\left(\mathrm{m}^{3}\right)$, dan $\rho$ adalah massa jenis singkong $\left(\mathrm{kg} / \mathrm{m}^{3}\right)$. 
Tabel 1. Parameter Pengujian

\begin{tabular}{|c|c|c|}
\hline Tujuan & Parameter & Analisis Data \\
\hline & Kapasitas teoretis & $\begin{array}{l}\text { Menghitung kapasitas kerja berdasarkan } \\
\text { sepesifikasi mesin }\end{array}$ \\
\hline & Kapasitas aktual & Melakukan pengujian unjuk kerja \\
\hline & Efisiensi & $\begin{array}{l}\text { Membandingkan kapasitas teoretis } \\
\text { dengan aktual }\end{array}$ \\
\hline & Ketebalan rata-rata irisan & $\begin{array}{l}\text { Mengukur } 100 \text { irisan sampel dan } \\
\text { dihitung rata-ratanya }\end{array}$ \\
\hline & Keragaman Irisan & $\begin{array}{l}\text { Menghitung standar deviasi dari } 100 \\
\text { sampel untuk mengitung koefisien dan } \\
\text { keseragaman }\end{array}$ \\
\hline & Persentase kerusakan & $\begin{array}{l}\text { Mengambil } 100 \text { gram sampel untuk } \\
\text { memisahkan dan menghitung irisan } \\
\text { rusak }\end{array}$ \\
\hline & Antropometri & - \\
\hline & Kebisingan & Pengambilan data \\
\hline & Getaran & Pengambilan data \\
\hline $\begin{array}{l}\text { Membandingkan kinerja } \\
\text { mesin }\end{array}$ & $\begin{array}{l}\text { Klasifikasi } \\
\text { Spesifikasi teknis Bahan dan } \\
\text { dimensi } \\
\text { Unjuk kerja mesin } \\
\end{array}$ & $\begin{array}{l}\text { Membandingkan berdasarkan hasil } \\
\text { kinerja mesin dengan standar SNI 0838- } \\
1: 2014\end{array}$ \\
\hline $\begin{array}{l}\text { Menganalisis kendala } \\
\text { saat pengoperasian } \\
\text { mesin }\end{array}$ & Hasil uji kinerja mesin & $\begin{array}{l}\text { Mengevaluasi kendala saat } \\
\text { pengoperasian mesin yang } \\
\text { menyebabkan tidak sesuai dengan } \\
\text { standar SNI 0838-1:2014 }\end{array}$ \\
\hline
\end{tabular}

\section{Kapasitas aktual pengirisan}

Kapasitas aktual merupakan kemampuan yang dimiliki suatu mesin untuk melakukan pengirisan singkong dalam selang waktu tertentu. Penghitungan kapasitas aktual mesin dapat dihitung dengan persamaan sebagai berikut (SNI 0838-1:2014):

$$
K a=60 * \frac{B i}{T i}
$$

dimana Ka adalah kapasitas pengirisan aktual (kg/jam), Bi adalah berat total singkong yang keluar dari mesin (kg), dan Ti adalah waktu yang dibutuhkan untuk pengirisan (menit).

\section{Efisiensi mesin pengiris}

Efisiensi adalah perbandingan antara kapasitas aktual dengan kapasitas teoretis. Efisiensi pengirisan dapat dihitung dengan persamaan sebagai berikut (Pasaribu, 2017):

$$
\varepsilon=\frac{K a}{K t} * 100 \%
$$

dimana $\varepsilon$ adalah efisiensi mesin (\%), Ka adalah kapasitas pengirisan aktual (kg/jam), dan $\mathrm{Kt}$ adalah kapasitas pengirisan teoretis ( $\mathrm{kg} / \mathrm{jam})$.

\section{Ketebalan rata-rata irisan}

Ketebalan rata-rata irisan dapat dihitung dengan menggunakan persamaan berikut (SNI 08381:2014).

$$
\operatorname{Tr}=\frac{1}{100} * \sum_{i=1}^{100} \mathrm{Ti}
$$

dimana Tr adalah tebal rata-rata irisan singkong $(\mathrm{mm})$ dan Ti adalah tebal irisan pada pengukuran ke-i (mm).

5. Keragaman ketebalan irisan Keragaman ketebalan irisan dapat dihitung dengan persamaan (SNI 0838-1:2014):

$$
\begin{aligned}
S D & =\sqrt{\frac{\sum_{i=1}^{100}(T i-T r)^{2}}{100}} \\
C V & =100 * \frac{S D}{T i} \\
U & =100-C V
\end{aligned}
$$


dimana SD adalah Standar Deviasi, CV adalah koefisien keragaman ketebalan irisan (\%), dan $\mathrm{U}$ adalah keragaman ketebalan irisan (\%).

6. Persentase kerusakan

Presentase kerusakan dapat dihitung menggunakan persamaan(SNI 0838-1:2014):

$$
P R=\frac{W r}{W s} * 100 \%
$$

Dimana adalah PR adalah persentase kerusakan (\%), Wr adalah berat rata-rata irisan rusak (g), dan Ws adalah berat rata-rata sampel (g).

\section{HASIL DAN PEMBAHASAN}

\subsection{Uji Kinerja Mesin}

\subsubsection{Uji Verifikasi}

Mesin pengiris singkong ertical berfungsi untuk mengiris tipis singkong sehingga dapat diolah lanjutan sebagai keripik singkong. Uji verifikasi pada mesin pengiris singkong bertujuan untuk memastikan kesesuaian mesin yang diproduksi dengan rancangan yang menjadi acuan dalam produksi mesin pengiris singkong ini. Hasil pengukuran dimensi mesin yang telah dipabrikasi menunjukkan kesesuaian antara desain yang dibuat dengan hasil pembuatan. Mesin pengiris singkong dalam penelitian ini ditunjukkan pada Gambar 1.

\subsubsection{Uji Unjuk Kerja}

Terdapat beberapa parameter dalam uji unjuk kerja. Berikut adalah beberapa parameter yang dianalisis:

\section{a. Bahan uji kinerja}

Sampel percobaan diukur panjang, diameter pangkal, tengah, dan ujung dengan menggunakan meteran dan jangka sorong. Hasil pengukuran menunjukkan rata-rata panjang singkong sebesar 206,03 mm. Adapun diameter bagian pangkal, diameter tengah, dan diameter ujung berturut-turut sebesar 43,92; 43,28; dan 24,25 $\mathrm{mm}$. Ketiga hasil pengukuran sampel memiliki rata-rata keragaman sebesar 78,89\%.

\section{b. Kondisi mesin}

Hasil pengukuran tanpa beban diperoleh penurunan putaran mesin. Penurunan tersebut dilihat dari spesifikasi mesin sebesar 3600 RPM menjadi 2966,27 RPM (menurun sebesar 17,6 $\%$ ) Kondisi mesin dengan menggunakan beban mengalami penurunan dari 2966,27 RPM menjadi 2934,88 RPM yang artinya mengalami penurunan sebesar (menurun 1,05\%) dan di setiap transmisi seperti gearbox dan as akan mengalami penurunan putaran sebesar $3,84 \%$.

\section{c. Kapasitas pengirisan}

Kapasitas mesin yang dirancang ini sebesar 25 $\mathrm{kg} /$ jam. Hasil rataan kapasitas aktual sebesar $18,51 \mathrm{~kg} / \mathrm{jam}$ dan memiliki keragaman sebesar $71,75 \%$. Terdapat beberapa kendala selama proses pengujian antara lain keahlian operator dalam mengoperasikan alat.

\section{d. Efisiensi kinerja mesin}

Efisiensi kinerja berdasarkan hasil pengujian mesin pengiris singkong sebesar 74,05\%. Nilai tersebut sudah di atas standar yang ditetapkan

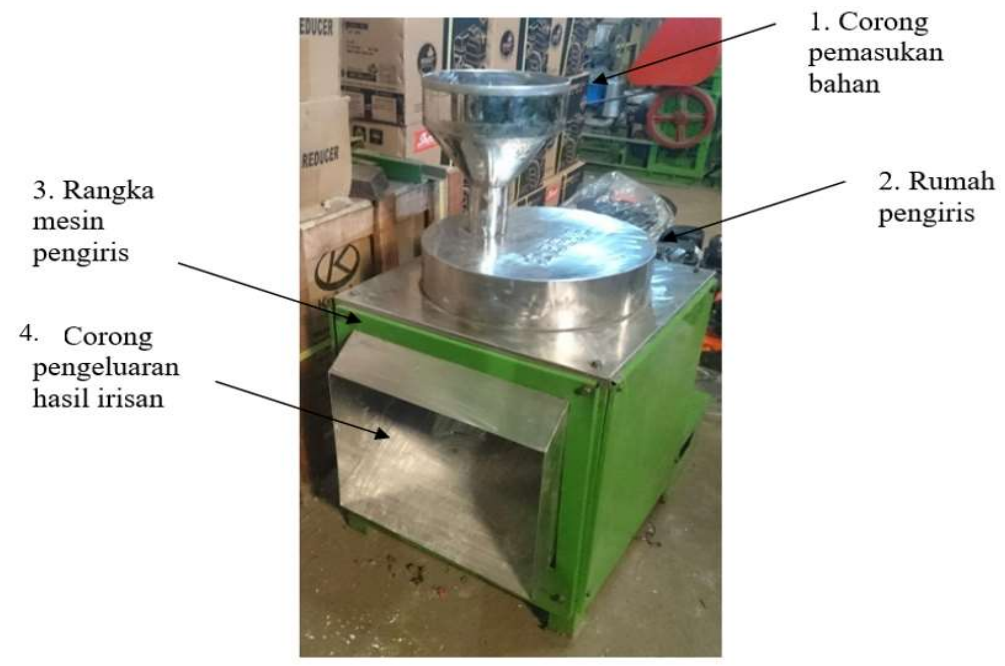

Gambar 1. Konstruksi Mesin Pengiris Singkong 
oleh SNI 7412:2008 mengenai efisiensi untuk mesin perajang yang memiliki nilai minimal efisiensi kerja sebesar $70 \%$.

\section{e. Keragaman irisan}

Hasil ketebalan irisan singkong pada mesin pengiris singkong dipengaruhi oleh ketebalan celah pisau yang sebesar $0,5 \mathrm{~mm}$. Pengaturan jarak mata pisau membutuhkan ketelitian karena harus menyesuaikan empat buah pisau pengiris. Tingkat presisi akan memengaruhi tingkat keragaman hasil irisan. Rataan hasil irisan yang diperoleh sebesar 0,73 mm. Rataan keragaman variasi sebesar $64,2 \%$.

\section{f. Kerusakan irisan}

Persentase perhitungan nilai kerusakan dengan mengambil sampel seberat 100 gram pada hasil irisan yang diujikan. Hasil perhitungan menunjukan persentase rata-rata irisan rusak sebesar 9,67\%.

\subsubsection{Uji Ergonomi}

\section{a. Antropometri}

Tinggi corong pengumpan dari lantai sebesar $995 \mathrm{~mm}$. Berdasarkan data antropometri orang Indonesia, diketahui bahwa tinggi tubuh rata-rata adalah $152,58 \mathrm{~cm}$, rataan panjang rentang tangan ke depan adalah $66,18 \mathrm{~cm}$, rataan panjang genggaman tangan ke depan adalah $64,51 \mathrm{~cm}$, dan tinggi siku dalam posisi berdiri rata-rata adalah 95,65 cm (Perhimpunan Ergonomi Indonesia, 2021). Oleh karena itu, tinggi corong tersebut sesuai dengan tinggi yang harus didesain untuk pekerjaan berdiri. Selain itu pengaturan tersebut meminimalisir cepatnya seseorang terkena lelah setelah bekerja. Tinggi corong tersebut operator dapat dengan mudah mengambil bahan yang berada dalam jangkauannya dan memasukkan bahan ke corong pengiris. Selain itu, jarak corong pemasukan ke tepi kerangka mesin adalah $5 \mathrm{~cm}$ artinya jarak tersebut masih dalam jangkauan rataan Panjang rentang tangan ke depan yang disyaratkan. Pengujian keergonomisan mesin dilakukan dengan cara survei pengoperasian mesin kepada 10 orang peserta. Hasil survei menunjukkan bahwa semua peserta menyatakan bahwa menghidupkan dan mengoperasikan alat termasuk kategori mudah. Selain itu, pekerjaan memasukkan singkong dan mengeluarkan hasil irisan juga mudah dilakukan.

\section{b. Kebisingan dan getaran mesin pengiris}

Tingkat kebisingan yang dihasilkan cukup tinggi yaitu sebesar 87,6 dB. Nilai ini masih di bawah standar yang telah ditentukan yaitu maksimal 90 dB (SNI 0838-1:2014). Adapun besarnya nilai getaran yang dihasilkan adalah 7,47 Hz (mesin tanpa beban) diukur pada kerangka maupun pada mesin. Hasil pengukuran pada mesin dengan menggunakan beban memperoleh nilai $7,40 \mathrm{~Hz}$ pada kerangka dan pada mesin. Sedangkan besar getaran tidak ditemukan ketentuan besar maksimalnya dalam SNI. Oleh karena itu, nilai 7,40 Hz masih dapat diterima.

\subsection{Kelayakan Mesin}

Klasifikasi mesin pengiris singkong yang dipabrikasi ini tergolong kelas A. SNI 08381:2014 menyatakan bahwa kelayakan mutu pada mesin pengiris singkong memiliki beberapa persyaratan seperti: spesifikasi teknis mesin, bahan, dan dimensi, serta persyaratan unjuk kerja.

\subsubsection{Spesifikasi teknis mesin}

Spesifikasi teknis pada mesin yang diproduksi jika dibandingkan dengan SNI 0838-1:2014 dilampirkan pada Tabel 2. Hasil pengukuran dimensi mesin dan dibandingkan dengan persyaratan menunjukkan mesin pengiris yang didesain memiliki dimensi yang lebih besar. Meskipun demikian, putaran poros as yang terukur cukup kecil yaitu hanya sebesar 49,7 RPM.

\subsubsection{Bahan dan dimensi}

Bahan yang digunakan untuk pembuatan rumah pengiris merupakan stainless steel food grade. Bahan tersebut juga digunakan untuk pisau pengiris. Bahan tersebut aman digunakan oleh alsin yang bertujuan untuk pengolahan hasil pertanian. Adapun rangka terbuat dari besi siku. Bahan yang digunakan dalam pembuatan mesin pengiris telah mengikuti standar tersebut mengacu pada SNI 0838-1:2014.

\subsubsection{Persyaratan unjuk kerja}

Hasil uji kinerja pada mesin pengiris singkong yang dipabrikasi menunjukkan bahwa ada tiga dari lima parameter dari standar yang ditentukan SNI 0838-1:2014 yang masih di bawah standar. Hal ini dapat disebabkan oleh beberapa faktor. Faktor pertama yang menyebabkan rendahnya 
Tabel 2. Perbandingan Mesin dengan Persyaratan SNI

\begin{tabular}{cccc}
\hline \multicolumn{1}{c}{ Parameter } & Satuan & Mesin produksi & Persyaratan \\
\hline Dimensi Keseluruhan & & & \\
- Panjang & $\mathrm{mm}$ & 985 & $500-600$ \\
- Lebar & $\mathrm{mm}$ & 555 & $400-500$ \\
- Tinggi & $\mathrm{mm}$ & 995 & $700-900$ \\
\hline Unit Pengiris dan dudukan pisau & & & \\
- Diameter piringan & $\mathrm{mm}$ & 410 & 200 \\
- Tebal & $\mathrm{mm}$ & 19 & 3 \\
- Jumlah pisau pengris & buah & 4 & $1-6$ \\
- Diameter poros as & $\mathrm{mm}$ & 25,4 & 25,4 \\
- Putaran poros as dengan beban & $\mathrm{RPM}$ & 49,7 & $200-500$ \\
\hline
\end{tabular}

Tabel 3. Persyaratan Unjuk Kerja

\begin{tabular}{lccc}
\hline \multicolumn{1}{c}{ Parameter } & Satuan & Uji mesin & Persyaratan \\
\hline Kapasitas pengirisan & $\mathrm{kg} / \mathrm{jam}$ & $18,51^{*}$ & Min 50 \\
Tebal rata-rata irisan & $\mathrm{mm}$ & $0,73^{*}$ & $1-3$ \\
Keragaman tebal irisan & $\%$ & $64,2^{*}$ & Min 85 \\
Persentase irisan rusak & $\%$ & 9,67 & Maks 20 \\
Kebisingan mesin & $\mathrm{dB}$ & 87,6 & Maks 90 \\
\hline
\end{tabular}

Keterangan: *parameter uji yang masih memerlukan perbaikan

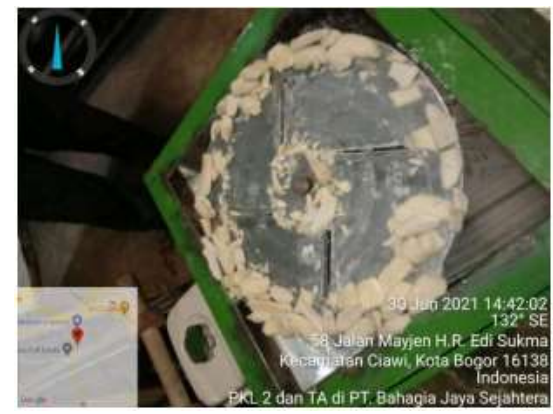

Gambar 2. Sisa Pengirisan yang Tertinggal di Pisau

kapasitas pengirisan dibandingkan dengan perencanaan adalah masih banyak sisa hasil pengirisan yang tertinggal di bagian dalam mesin pengiris (Gambar 2). Faktor kedua adalah ketebalan irisan yang masih di bawah standar disebabkan oleh pengaturan pisau pengiris yang masih manual dan perlu penyesuaian. Hal ini pada akhirnya berpengaruh pada keragaman tebal irisan yang juga masih di bawah standar. Hasil perbandingan pengujian kinerja dengan standar kelayakan dapat dilihat pada Tabel 2.

\subsection{Analisis Kendala Mesin}

\subsubsection{Pisau pengiris}

Mata pisau yang digunakan dalam mesin pengiris ini dibuat dari pelat stainless steel. Material yang dipilih tersebut aman digunakan (food grade). Meskipun demikian, pisau tersebut mudah tumpul. Oleh karena itu, perlu dipertimbangkan untuk saat proses produksi agar disediakan pisau cadangan untuk menggantikan pisau yang $d$ ajika sewaktu-waktu diperlukan. Pengaturan pemasangan pisau memiliki tingkat kesulitan yang tinggi untuk mendapatkan jarak pisau yang diinginkan. Oleh karena itu, diperlukan perbaikan rancangan berupa dudukan pisau yang dapat diatur sesuai dengan kebutuhan untuk mengatur kemiringan pisau dan jarak celah pisau. Selain itu, diperlukan modifikasi untuk mempermudah pemasangan dan penggantian pisau. 


\subsubsection{Transmisi}

Putaran poros pengiris dengan beban yang sesuai SNI 0838-1:2014 adalah sebesar 200-500 RPM. Motor penggerak yang digunakan dalam penelitian ini adalah motor bensin dengan daya maksimum 4,1 kW. Motor ini memutar gearbox untuk kemudian memutar as dan piringan pisau pengiris. Putaran pada mesin pengiris yang diujikan pada penelitian ini sebesar 49,7 RPM karena mengalami reduksi 1:30. Oleh karena itu, perlu dipilih gearbox yang menghasilkan rasio putaran 1:10.

\section{KESIMPULAN}

Hasil penelitian uji kinerja mesin pengiris singkong diperoleh hasil bahwa mesin pengiris singkong yang dipabrikasi sesuai dengan spesifikasi teknis rancangan. Adapun hasil uji unjuk kerja, diperoleh bahwa kapasitas pengirisan singkong sebesar $18,51 \mathrm{~kg} / \mathrm{jam}$ dengan efisiensi kinerja 74,05\%. Hasil pengirisan memiliki ketebalan rata-rata sebesar $0,73 \mathrm{~mm}$, tingkat keseragaman $64,2 \%$, dan memiliki nilai kerusakan irisan sebesar 9,67\%. Hasil uji ergonomi mesin yang diproduksi berdasarkan hasil survei menunjukkan bahwa mesin mudah untuk dioperasikan. Hasil perbandingan yang mengacu pada SNI 0838-1:2014 menunjukkan mesin pengiris singkong vertikal yang dipabrikasi masih perlu diperbaiki pada beberapa parameter unjuk kerja seperti kapasitas pengirisannya, tebal rata-rata irisan, dan keragaman tebal irisan.

\section{DAFTAR PUSTAKA}

BPS (Badan Pusat Statistik) Kabupaten Bogor. 2021. Luas tanam, Produksi Ubi Kayu Kabupaten Bogor. Bogor: Badan Pusat Statistik Kabupaten Bogor

BSN (Badan Standardisasi Nasional). 2014. SNI 0838-1:2014 Mesin Pengolah Ubi Kayu Bagian 1: Mesin Pengiris Ubi Kayu-Syarat Mutu dan Metode Uji. Jakarta: Badan Standardisai Nasional

BSN (Badan Standardisasi Nasional). 2008. SNI 7412:2008 Mesin pencacah hijau pakan (chopper) - Unjuk kerja. Jakarta: Badan Standardisasi Nasional

Perhimpunan Ergonomi Indonesia. 2021. Rekap Data Antropometri Indonesia. https:// www.antropometriindonesia.org/ index.php / detail /artikel/4 / 10 / data_antropometri [diakses pada 17 Desember 2021]

Azharul, F., Yandi, A., Firmansyah, A., dan Hadi, V. 2020. Perancangan mesin pengiris singkong. Jurnal Terapan Teknik Mesin, 1(2): 41-53. DOI: $10.37373 /$ msn.v1i2.49

Handayani, T.H.W., dan Marwanti. 2011. Pengolahan Makanan Indonesia. Yogyakarta: Kementrian Pendidikan Nasional, Universitas Negeri Yogyakarta.

Husman, H dan Ariyono, S. 2018. Rancang Bangun Mesin pengiris Singkong. Jurnal ManuTech, 10(2): 31-34. https://doi.org/ 10.33504/manutech.v10i02.65

Pasaribu, A.J.P. 2017. Rancang Bangun dan Uji Kinerja Mesin Pengiris Talas. Skripsi. Program Studi Teknik Pertanian, Fakultas Teknologi Industri Pertanian, Universitas Padjadjaran, Jatinangor, Bandung.

Sateria, A., dan Darta, Y. 2020. Rancang bangun mesin pengiris keripik singkong. Jurnal NCIET, 1(1): A160-A165. DOI: https:// doi.org/10.32497/nciet.v1i1.141

Suriadi, I.G.A.K., Subagia, I.D.G.A., dan Atmika, I.K. 2016. Penerapan mesin pengiris singkong pada industri kecil kripik singkong. Jurnal Udayana Mengabdi, 1 (2): 118-124

Sugandi, W.K., Kramadibrata, M.K.A.M., Widyasanti, A., dan Putri, A.R. 2017. Uji kinerja dan analisis ekonomi mesin pengupas Bawang Merah (MPB TEP0315). Jurnal Ilmiah Rekayasa Pertanian dan Biosistem, 6(2): 440-451.

Widiyarta, I.M., Negara, D.N.K.P., dan Muku, I.D.M.K. 2018. Rancang bangun alat pemotong/pengiris bahan baku krupuk terigu dan kripik singkong. Jurnal Buletin Udayana Mengabdi, 17 (1): 187-191. 